\title{
Eksistensi Manajemen Pemasaran dalam Membangun Citra Lembaga Pendidikan
}

\author{
Toha Ma'sum ${ }^{1}$ \\ ${ }^{1}$ STAI Darussalam Nganjuk \\ ${ }^{1}$ mahsuntoha81@gmail.com
}

\begin{abstract}
The school image and the efforts to create a positive image can not be separated from the school efforts it self, especially for the public relations department. Public relations in education have some special tasks, including; evaluating attitudes and public opinions toward the organization, formulation and implementation the procedures and organization policies for communicate with the public, coordinating communication programs between organizations with the public, developing relationship throught communication procces, developing attitude and possitive relationship between organization and public, and also creating public perception and good image for the institution. The marketing management education services can apply the theory of marketing management. It is including; marketing planning, marketing organizing, marketing implementation, and marketing supervision. The effort to improve and maintain a possitive image is an academic reputation/ quality. It can be realized with improving the quality of education services, improving education services products, and adding many other efforts in the form of building communication, implementing discipline, giving direction to the alumni to maintain the good name of the institution. The existence of marketing education services in enhancing the image is that marketing education services is Carried out by promoting the excellent learning programs, the possitive activities outside the school, and well-planned program planning will be success in creating and maintaining the image of the school.
\end{abstract}

\section{Key Word: Educational Institutions, Imagery, Marketing Management}

Abstrak
Citra sekolah dan usaha-usaha untuk menciptakan citra positif, tidak lepas dari usaha pihak sekolah terutama bagian humas. Humas dalam pendidikan memiliki tugas khusus diantaranya yaitu melaksanakan evaluasi terhadap sikap dan pandangan masyarakat (publik) terhadap organisasi, formulasi dan mengimplmennasikan prosedur dan policy (kebijakan) organisasi terhadap komunikasi organisasi dengan masyarakat (publik), mengkoordinasikan programprogram komunikasi organisasi dengan publik, mengembangkan hubungan melalui proses komunikasi, mengembangkan sikap dan hubungan positif antara organisasi dengan publik, serta menciptakan persepsi publik dan citra yang baik untuk lembaga. Manajemen pemasaran jasa pendidikan dapat menerapkan teori manajemen pemasaran meliputi perencanaan pemasaran, pengorganisasian pemasaran, pelaksanaan/implementasi pemasaran, dan pengawasan pemasaran. Usaha meningkatkan dan mempertahankan citra positif adalah academic reputation/mutu akademik, dan mewujudkannya dengan langkah meningkatkan kualitas jasa pendidikan, meningkatkan produk jasa pendidikan, dan ditambah usaha 
lainnya berupa membangun komunikasi, menerapkan kedisiplinan, memberikan pengarahan kepada alumni agar senantiasa menjaga nama baik almamater. Eksistensi pemasaran jasa pendidikan dalam meningkatkan citra adalah bahwa pemasaran jasa pendidikan yang dilaksanakan dengan jalan promosi program pembelajaran unggulan, kegiatan positif di luar sekolah, dan dengan perencanaan program yang tersistem dengan baik akan berhasil meningkatkan dan mempertahankan citra sekolah.

Kata Kunci: Citra, Lembaga Pendidikan, Manajemen Pemasaran

\section{Pendahuluan}

Pendidikan pada dasarnya merupakan suatu upaya, pengaruh, perlindungan, serta bantuan yang diberikan kepada anak. Adapun usaha-usaha tersebut dilaksanakan oleh orang dewasa dengan memberikan impuls kepada anak melalui berbagai macam cara. Salah satunya dengan adanya sekolah yang nantinya akan membantu orang tua untuk memberikan pendidikan kepada anak. ${ }^{1}$

Sekolah adalah lembaga nonprofit yang bergerak di bidang jasa pendidikan dan merupakan wadah berlangsungnya pendidikan, yang di dalamnya fokus pada pendidikan yang tujuannya adalah adanya peningkatan dan pengembangan kualitas sumber daya manusia. Sekolah dikatakan sebagai sistem ketika mencakup beberapa komponen, komponen-komponen tersebut meliputi input, proses, output dan outcome. ${ }^{2}$

Untuk menjaga kelestariannya, sekolah harusnya mengejar serta merespon apa yang menjadi kebutuhan stakeholder. Maksudnya adalah harus ada upaya sekolah yang mampu meningkatkan input serta sumber daya untuk memenuhi kebutuhan dalam proses mencetak lulusan. Lingkungan sekolah pada umumnya selain berkompetisi bidang prestasi pendidikan, bidang kesehatan sekolah, juga bersaing dalam mempertahankan serta tujuan lain demi melestarikan sumber-sumber pendanaan. $^{3}$

Dewasa ini pemasaran mulai dilakukan oleh lembaga pendidikan tujuannya tidak lain untuk menjadi pemenang atas persaingan antara lembaga pendidikan lainnya. Dengan menerapkan pemasaran pada lembaga pendidikan diharapkan nantinya mampu memperkenalkan pendidikan pada masyarakat luas dan nantinya akan mempermudah memperoleh input peserta didik baru. Dalam pemasaran jasa pendidikan setidaknya perlu memperhatikan aspek kebutuhan pengguna serta pelanggan jasa pendidikan dengan memberikan penawaran produk yang sesuai dengan masyarakat yang membutuhkan yang 
dilakukan dengan pengolahan pemasaran jasa pendidikan. ${ }^{4}$

Pelayanan baik oleh penyedia jasa akan membentuk physical evidence pelanggan, dengan adanya physical evidence pelanggan yang telah terbentuk akan memungkinkan terjadinya peningkatan jumlah pelanggan jasa pendidikan. ${ }^{5}$

Pada era modern ini eksistensi sekolah ditentukan oleh aspek kualitas jasa pendidikan, karena wujud dari keberhasilan jasa pendidikan adalah adanya pemberian layanan pendidikan yang berkualitas pada pelanggan jasa pendidikan (siswa). ${ }^{6}$ Dengan adanya jasa pendidikan yang berkualitas maka akan terbentuk sebuah image atau citra sekolah.

Berkiblat pada citra positif sekolah, seorang pemimpin atau pengelola sebuah pendidikan, tentunya mengharapkan adanya citra positif tersebut, hal ini dikarenakan akan menentukan posisi. Penentuan posisi merupakan sebuah harapan atau penilaian terhadap sekolah, merek pendidikan, atau sebuah bentuk produk jasa lainnya. Citra sekolah sudah dibentuk oleh pihak pemasar jasa pendidikan secara proaktif dan progresif

\footnotetext{
${ }^{4}$ Suvidiana Elytasari, "Strategi Pemasaran Jasa Pendidikan Untuk Meningkatkan Kepercayaan (Trust) Stakeholders di TK Amal Insani Depok Yogyakarta" dalam Jurnal Warna vol. 1, no. 1, (Juni 2017), 119.

${ }^{5}$ Sumaryanto, "Strategi Sukses Bagi Usaha Pemasaran Jasa Pendidikan Berbasis Manajemen Proses", dalam Jurnal Ekonomi Dan Kewirausahaan, vol. 11, no. 1, (April 2011), 50.

${ }^{6}$ David Wijaya, Pemasaran Jasa Pendidikan, sebagaimana tema ini, maka untuk

${ }^{7}$ Ibid., 64 .

${ }^{8}$ Abdul Rahmad, Manajemen Humas Sekolah, (Yogyakarta: Media Karya, 2016), 15.

${ }^{9}$ Frazier Moore, Humas membangun citra dengan komunikasi, ( Bandung: remaja rosdakarya, 2005), 6.

melalui komunikasi pemasaran jasa pendidikan yang dilaksanakan secara sistematis dan terpadu. ${ }^{7}$ Berdasarkan kategori tesebut dapat dipahami bahwa berbagai aspek yang mempengaruhi citra positif sekolah akan mempengaruhi input (jumlah siswa yang mendaftar).

Jika kita meneliti terkait dengan citra sekolah dan usaha-usaha menciptakan citra positif, pastinya tidak lepas dari usaha pihak sekolah terutama bagian humas. Humas dalam pendidikan memiliki tugas khusus di antaranya yaitu melaksanakan evaluasi terhadap sikap dan penilaian (opini) publik (masyarakat) terhadap organisasi, formulasi dan perwujudan prosedur dan kebijakan (policy) organisasi atas komunikasi organisasi yang dilaksanakan oleh lembaga dengan publik, mengoordinasikan programprogram komunikasi antara organisasi dengan publik, mengembangkan hubungan melalui proses komunikasi, mengembangkan sikap dan hubungan positif antara organisasi dengan publik. ${ }^{8}$ Serta menciptakan persepsi publik dan citra yang baik untuk lembaga. ${ }^{9}$

\section{Metode Penelitian}

Berdasarkan atas tema penelitian 
mengamati dan menganalisis data dan merupakan data yang harus diperoleh menguji kebenaran suatu data, maka langsung dari sumbernya. ${ }^{13}$ Adapun sumber pendekatan yang digunakan penulis adalah data primer yang peneliti gunakan adalah: menggunakan pendekatan kualitatif. buku Agustina Shinta, Manajemen Pendekatan kualitatif merupakan pendekatan Pemasaran, Buchari Alma, Manajemen penelitian yang melalui proses penemuan dan Pemasaran dan Pemasaran Jasa Pendidikan, pengumpulan, menganalisis dan David Wijaya, Pemasaran Jasa Pendidikan, menginterprestasi data visual dan naratif Frazier Moore, Humas membangun citra yang komprehensif dan bertujuan untuk dengan komunikasi, Manullang dan memahami suatu fenomena atau masalah Esterlina, Manajemen Pemasaran, Rambat yang dialami dan menarik perhatian. ${ }^{10}$

Adapun jenis penelitian yang digunakan adalah jenis penelitian literature atau Lupiyoai dan A. Hamdani, Manajemen Pemasaran Jasa edisi 2, dan buku Samsul kepustakaan (library reasearch). Penelitian Anam, dkk., Manajemen Pemasaran. kepustakaan merupakan suatu bentuk studi penelitian yang menekankan pada pustaka sebagai suatu objek studi. ${ }^{11}$

Penelitian ini merupakan penelitian kepustakaan (library research) maka dari itu penelitian ini menggunakan sumber data primer dan sumber data sekunder. Yang dimaksud dengan sumber data adalah subjek dari mana data dapat diperoleh. ${ }^{12}$ Data sekunder merupakan data yang lebih cepat dan lebih mudah diperoleh karena sudah tersedia, misalnya di perpustakaan, perusahaan, organisasi, kantor pemerintahan dan lain sebagainya. Sedangkan data primer

Untuk mendapatkan data yang akurat, untuk menunjang penelitian ini, maka teknik pengumpulan data yang digunakan berupa metode dokumentasi. Menurut A. Muri Yusuf metode dokumentasi adalah mencari data tentang seseorang atau sekelompok orang, peristiwa, atau kejadian dalam situasi sosial yang sesuai dan terkait dengan fokus penelitian. ${ }^{14}$ Sedangkan menurut Suharsimi Arikunto metode dokumentasi merupakan teknik pencarian data melalui hal-hal atau variabel yang berupa catatan, transkrip, buku, surat kabar, majalah, peraturan-peraturan, agenda dan sebagainya. ${ }^{15}$

Dalam penelitian ini teknis analisis data yang digunakan adalah teknik analisis isi

${ }^{10}$ A. Muri Yusuf, Metode Penelitian Kuantitatif, Kualitatif dan Gabungan (Jakarta: Kencana, 2017), 330.

${ }^{11}$ Ibnu Subiyanto, Metodologi Penelitian (TT: Universitas Gunadarma, TT), 93.

${ }^{12}$ Suharsimi Arikunto, Prosedur Penelitian Suatu Pendekatan Prakti (Jakarta: Rineka Cipta, 2014), 72.
${ }^{13}$ Jonathan Sarwono, Metode Penelitian Kuantitatif dan Kualiitatif (Yogyakarta: Graha Ilmu, 2006), 123-124.

${ }^{14}$ Yusuf, Metode penelitian Kuantitatif, Kualitati..., 391.

${ }^{15}$ Suharsimi Arikunto, Prosedur Penelitian (Jakarta: Pt Rineka Cipta, 2010), 190. 
(content analysis). Teknik analisis isi (content analysis) adalah teknik yang dipakai untuk menarik kesimpulan melalui sebuah usaha menemukan karakteristik pesan, yang pengerjaannya dilakukan secara objektif dan sistematis. Selain itu content analysis juga digunakan untuk membandingkan isi buku dengan buku lain yang masih mempunyai bidang kajian yang sama, baik berdasarkan pada perbedaan waktu, maupun mengenai kemampuan buku. ${ }^{16}$

\section{Hasil Penelitian dan Pembahasan}

\section{Pembahasan}

\section{A. Manajemen}

Pemasaran

\section{Pendidikan}

1. Definisi Manajemen Pemasaran Jasa Pendidikan

a. Manajemen Pemasaran

Manajemen merupakan suatu ilmu dan seni dalam mengatur, mengendalikan, mengomunikasikan serta memanfaatkan segala sumber daya yang terdapat dalam suatu organisasi dengan memanfaatkan fungsi-fungsi dari unsur-unsur manajemen (Planing, Organizing, Actuating, Controling) agar suatu organisasi mampu mencapai tujuan yang ditetapkan secara efektif dan efesien. ${ }^{17}$

\footnotetext{
${ }^{16}$ Burhan Bungin, Metode Penelitian Kualitatif (Jakarta: PT. Raja Grafindo Persada, 2001), 172-173.

${ }^{17}$ Muhammad Kristiawan, Dkk, Manajemen Pendidikan, (Yogyakarta: Deepublish, 2017), 1.
} Jurnal Intelektual: Jurnal Pendidikan dan Studi Keislaman Volume 10, Nomor 2, Agustus 2020
Hersey dan Blanchard sebagaimana yang dikutip oleh Candra dalam bukunya Dasar-Dasar Manajemen "management is a process of working with amd through individuals and groups and other resources to accomplish organizational goals". Manajemen adalah proses kerjasama antara individu dan kelompok serta sumber daya lainnya untuk mencapai tujuan organisasi. ${ }^{18}$

Manajemen pemasaran merupakan suatu usaha untuk merencanakan, mengimplementasikan,mengorganisasikan, serta mengawasi kegiatan pemasaran melalui adanya sebuah organisasi dengan tujuan untuk memeroleh hasil yang maksimal, efektif dan efisien. Dalam pemasaran sendiri terdapat beberapa hal yang perlu dipertimbangkan pada mulanya, di mana hal ini bertujuan untuk mengetahui keadaan pasar serta lingkungannya sehingga nantinya dapat diketahui seberapa besar peluang dan seberapa besar ancaman di lapangan yang harus dihadapi. ${ }^{19}$

$\begin{array}{rcr}\text { Philip } & \text { Kotler dan } & \begin{array}{r}\text { Amstrong } \\ \text { menyatakan }\end{array} \\ \text { bahwasanya } & \text { marketing }\end{array}$
management is the analysis, planing, implementation, and control of programs sign to creat, buidl, and maintain beneficial exchanges with target buyers for the purpose of achieving organizational objectivies",

${ }^{18}$ Candra Wijaya dan Muhammad Rifa'i, Dasar-Dasar Manajemen (Medan: Perdana Publishing, 2016), 14-15.

${ }^{19}$ Agustina Shinta, Manajemen Pemasaran m 
yang dimaksud manajemen pemasaran berjalan dengan efektif dan efisien. adalah suatu kegiatan menganalisis, Adapun konsep-konsep tersebut meliputi:

merencanakan, mengimplementasikan, dan mengawasi segala bentuk kegiatan untuk mendapatkan keuntungan dari kedua belah pihak agar mencapai tujuan organisasi.

William J. Shultz menyatakan bahwa "marketing management is the planing, direction and control of the entire marketing activity of a firm or division of a firm", manajemen pemasaran adalah suatu proses kegiatan merencanakan, pengarahan, dan pengawasan seluruh kegiatan pemasaran dalam suatu organisasi atau perusahaan. ${ }^{20}$

Dari uraian tentang manajemen pemasaran sebagaimana paparan diatas dapat disimpulkan bahwa manajemen pemasaran adalah kegiatan yang dijalankan untuk mencapai tujuan organisasi dari segi pemasaran melalui fungsi manajemen yang meliputi perencanaan (planing), pengarahan (actuating) dan pengawasan kegiatan pemasaran (controling).

1) Konsep Pemasaran

Pemasaran merupakan usaha untuk menjual atau menawarkan produknya. Agar pemasaran berjalan secara efektif dan efisien maka perlu memperhatikan konsep pemasaran, yang di mana nantinya konsep tersebut akan berkonsentrasi pada setiap aspeknya, sehingga pemasaran akan

${ }^{20}$ Buchari Alma, Manajemen Pemasaran dan Pemasaran Jasa (Bandung: Alfabeta, 2018), 131. a) Konsep Produksi

Konsep produksi merupakan konsep yang fokus pada produk yang disukai konsumen yang banyak beredar disekitar konsumen serta tetap mempertimbangkan kemampuannya untuk memproduksi. Konsep produksi berkonsentrasi dan fokus pada peningkatan efisiensi produksi dan efisiensi distribusi.

b) Konsep Produk

Konsep ini fokus pada perbaikan dan pengembangan produk karena dengan produk yang yang baik akan berdampak pada konsumen. Produk dengan kualitas yang baik akan mampu menarik konsumen.

c) Konsep Penjualan

Konsep ini menggunakan usaha seperti promosi untuk mendongkrak penjualan. Dengan adnya promosi dan penawaran yang menarik akan mampu mempengaruhi konsumen.

d) Konsep Pemasaran

Konsep pemasaran mengarah pada beberapa aspek yang perlu dipertimbangkan antar lain produk (jenis produk, inovasi produk, dsb.), target customer dari segi kebutuhan dan keinginan.

e) Konsep Pemasaran Sosial 
Konsep pemasaran sosial yang sesuai dengan kondisi dan kebutuhan menyatakan memenuhi kebutuhan, konsumen.

keinginan dan kepentingan konsumen yang mampu meningkatkan kesejahteraan konsumen akan meningkatkan

kepercayaan

konsumen

perusahaan. $^{21}$

\section{b. Pemasaran Jasa Pendidikan}

Pemasaran dalam konteks jasa pendidikan merupakan sebuah kegiatan manajerial guna memperoleh, memberikan apa yang diperlukan, serta yang diinginkan dengan menciptakan penawaran dan pertukaran produk yang memiliki nilai pada pihak lain dalam bidang pendidikan.

Etika pemasaran dalam dunia pendidikan adalah memberikan penawaran mutu atas layanan intelektual kepada konsumen dan pembentukan watak pada obyek pendidikan secara menyeluruh.

Dan Steinhoff mengemukakan "the raw material of services is people”, bahan baku untuk menghasilkan jasa adalah orang. Dalam hal ini, yang dimaksud orang adalah seseorang yang mempunyai ciri khas berbeda antara satu dengan lainnya, pepatah mengatakan bahwa tidak ada manusia yang memiliki persamaan bahkan anak kembar sekalipun.

Hal tersebut menjadi sebuah dasar bahwa akan pelayanan jasa pendidikan antar lembaga satu dengan lainnya akan berbeda,

${ }^{21}$ Samsul Anam, dkk., Manajemen Pemasaran (Surabaya: IAIN Sunan Ampel, 2013), 13-14. Jurnal Intelektual: Jurnal Pendidikan dan Studi Keislaman Volume 10, Nomor 2, Agustus 2020
Dengan pertimbangan karakteritik sebagaimana tersebut diatas, jasa pendidikan akan diterima setelah terjadi interaksi dengan sumber terpercaya atau penghubung. Dalam hal ini, faktor yang sanget berpengaruh adalah siapa, kapan dan dimana jasa tersebut diproduksi.

Dari sini dapat dipahami bahwa pada dasarnya keberhasilan suatu pendidikan sangat tergantung pada siapa, kapan dan dimana proses tersebut terlaksana. ${ }^{22}$ Adanya peningkatan dari beberapa aspek perusahaan jasa merupakan harapan utama dari perusahaan jasa. Maka dari itu perlu menjalankan tugas-tugas perusahaan jasa yang meliputi: ${ }^{23}$

1) Diferensiasi pengelolaan

$$
\text { Membedakan aspek-aspek }
$$

pemasaran seprti persaingan, penawaran dan citra, adapun untuk membedakan perusahaan jasa tersebut dengan perusahaan lain perlu adanya tindakan inovatif terhadap aspek-aspek pemasaran.

2) Mengelola Mutu Pelayanan

$$
\text { Mengelola mutu pelayanan }
$$
merupakan usaha untuk meningkatkan komponen-komponen dalam pemasaran jasa dan apabila mutu komponen-

\footnotetext{
${ }^{22}$ Abdul Rahmat, Manajemen Humas Sekolah (Yogyakarta: Media Akademi, 2016), 93-94.

${ }^{23}$ Manullang dan Esterlina, Manajemen Pemasaran (Yogyakarta: Indomedia Pustaka, 2016), 65-66.
} 
komponen tersebut ketika telah terbilang manajemen yakni planing, organizing, baik maka nantinya akan mampu actuating dan controling. Sehingga mempengaruhi tingkat kuantitas dihubungkan dengan kegiatan pendidikan konsumen serta kepercayaan konsumen, maka mnjemen tersebut untuk memasarkan adapun tahap awal perusaahan jasa untuk jasa pendidikan.

mngelola mutu pelayanan perlu 1) Planing (Perencanaan)

mengadakan identifikasi keinginan

Mondy \& Premeaux

konsumen dengan memperhatikan menjelaskan "planning is the process of beberapa kriteria yaitu: akses, komunikasi, kompetensi, pegawai yang ramah dan cepat tanggap, kredibilitas, keandalan, responsif, keamanan, nyata, dan memahami konsumen.

3) Mengelola Produktivitas

Mengelola produktivitas perusahaan jasa merupakan usaha untuk meningkatkan produktivitas pelayanan, sehubungan dengan hal tersebut perlu menggunakan beberapa cara yaitu:

a) Bekerja keras sesuai dengan keahlian khusus dibidangnya

b) Meningkatkan jumlah pelayanan

c) Mengindustrialisasikan pelayanan

d) Mendesain pelayanan dengan pelayanan yang inovatif dan efektif

e) Memberikan pelayanan konsumen bebas melakukan apa yang dilakukan pelayan.

c. Manajemen Pemasaran Jasa Pendidikan

Berdasarkan teori yang dikutip oleh Agustina Shinta dalam bukunya manajemen pemasaran, dapat difahami bahwasanya manajemen pemasaran terdiri dari fungsi determining in advance what should be accomplished and how it should be realized".

Perencanaan adalah proses menentukan apa yang seharusnya dicapai dan bagaimana cara mewujudkannya dalam sebuah kenyataan. Sehingga dapat digaris bawahi bahwasanya perencanaan menjadi landasan melaksanakan program dengan adanya rencana atau cara-cara untuk mencapai tujuan bersama. ${ }^{24}$

a) Identifikasi Pasar

Identifikasi pasar adalah sebuah proses penelitian secara seksama untuk memperoleh data riil tentang kondisi dan ekspektasi pasar, termasuk dalam proses ini adalah atribut-atribut pendidikan yang menjadi kepentingan konsumen pendidikan. ${ }^{25}$

Selain itu tujuan diadakannya identifikasi sendiri adalah untuk menganalisis peluang jangka panjang

${ }^{24}$ Candra Wijaya dan Muhammad Rifa'i, Dasar-Dasar Manajemen, 27-28.

${ }^{25}$ Abdul Rahmat, Manajemen Humas Sekolah ., 
yang di mana peluang ini digunakan untuk memperbaiki kinerja. ${ }^{26}$

b) Segmentasi dan Positioning

Segmentasi pasar adalah proses memilah pasar menjadi beberapa golongan pembeli yang dibedakan berdasarkan kebutuhan, karakteristik, serta tingkah laku yang memungkinkan adanya kebutuhan produk yang berbeda. Sebelum membagi pasar dan memilahnya pada segmen tertentu, biasanya dilakukan riset pasar terlebih dulu. $^{27}$

Tujuan diadakannya segmentasi adalah untuk memberikan pelayanan kepada konsumen secara lebih baik dan memperbaiki posisi kompetitif suatu perusahaan terhadap pesaingnya, selain itu juga untuk meningkatkan penjualan, meningkatkan pangsa pasar, melakukan promosi dan komunikasi serta memperkuat citra. $^{28}$

Namun ada kalanya segmentasi sebagai alat penentu pasar dapat berjalan sesuai fungsinya dengan mempertimbangkan beberapa aspek, seperti segmentasi demografis (kependudukan baik dari segi identititas perseorangan, finansial,

${ }^{26}$ Thamrin Abdullah dan Francis Tantri, Manajemen Pemasaran (Depok: Raja Grafindo Persada, 2012), 49.

${ }^{27}$ Rambat Lupiyoai dan A. Hamdani, Manajemen Pemasaran Jasa edisi 2, (Jakarta: Salemba Empat, 2006), 44 ${ }^{28}$ Ibid., 46 sosial ekonomi, dan sebagainya), segementasi psikologis (gaya hidup masyarakat), segmentasi geografis (tingkat kepadatan penduduk, keadaan iklim, dan sebagainya), segmentasi manfaat, dan segmentasi penggunaan. ${ }^{29}$ Dalam segmentasi terdapat beberapa tahapan yang harus dilalui, beberapa langkah tersebut meliputi:

1) Mendefinisikan pasar yang menjadi sasaran.

2) Mengidentifikasi pasar (mengenali pasar).

3) Memilih pasar terbaik untuk segmentasi.

4) Mengidentifikasi pasar individu, menunjukkan daya tarik, menyeleksi segmentasi. ${ }^{30}$

5) Menentukan tujuan pemasaran.

6) Menentukan strategi.

7) Menentukan sistem organisasi pemasaran.

8) Menentukan sistem pengendalian pemasaran. $^{31}$

Positioning merupakan kegiatan yang memuat kegiatan awal seperti perancangan dan penawaran citra perusahaan agar mampu menarik perhatian target pasar dan mengetahui

${ }^{29}$ Ibid., 47

${ }^{30}$ Ibid., 47

${ }^{31}$ Samsul Anam, dkk., Manajemen Pemasaran 
posisi suatu perusahaan di mata for the purpose of achieving some goal or pesaing. Sehingga dapat disimpulkan positioning merupakan strategi untuk memilih pesaing yang setara. ${ }^{32}$ Menurut teori Kotler, langkah-langkah melakukan positioning ada 3 (tiga) yaitu: ${ }^{33}$

1) Mengetahui keunggulan dan kelemahan

2) Memilih dan menentukan keunggulan yang paling kuat

3) Menyampaikan informasi keunggulan pada target pasar.

c) Diferensiasi Produk

Diferensiasi produk adalah usaha untuk membedakan hasil produk dengan jalan mengubah bentuk produknya, menetapkan kinerja produk dan rancangan produk yang memiliki kualitas unggul dan unik, serta menciptakan inovasi produk yang berbeda dengan pasaran. ${ }^{34}$

\section{2) Organizing}

Terry menjelaskan: "Organizing is the establishing of effective behavioral relationship among persons, so that they may work together efficiently and gain personal satisfaction in doing selected task under given environmental conditions

${ }^{32}$ Rambat Lupiyoai dan A. Hamdani, Manajemen Pemasaran Jasa edisi 2, 58.

${ }^{33}$ Ibid., 58.

${ }^{34}$ David Wijaya, Pemasaran Jasa Pendidikan (Jakarta: Bumi Aksara, 2016), 60.

objective”.

Maksud dari pendapat tersebut di atas adalah bahwa pengorganisasian merupakan suatu usaha penciptaan hubungan tugas yang jelas antara personalia dalam sebuah organisasi atau sekelompok individu, sehingga dengan demikian setiap personil mampu bekerjasama dalam situasi dan kondisi yang baik untuk mencapai tujuan-tujuan yang telah ditetapkan oleh organisasi. Fungsi dari pengorganisasian yang dilakukan oleh seorang manajer adalah :

a) Memberikan penjelasan tentang siapa yang akan melakukan apa

b) Memberikan penjelasan tentang siapa memimpin siapa

c) Memberikan penjelasan tentang saluran-saluran komunikasi

d) Memusatkan sumber-sumber data terhadap sasaran-sasaran. ${ }^{35}$

Berdasarkan beberapa fungsi dari manajer dalam organisasi yang telah disebutkan di atas dapat disimpulkan bahwa manajer tidak bekerja sendirian, dalam suatu perusahaan atau instansi besar akan ada beberapa spesialis pemasaran seperti wiraniaga, manajer penjualan, peneliti pemasaran, staf iklan, manajer produk dan merek, manajer

${ }^{35}$ Candra Wijaya dan Muhammad Rifa'i, Dasar-Dasar Manajemen., 40. 
segmen pasar dan staf pelayanan pelanggan. $^{36}$

3) Actuating (penggerakan)

Actuating (penggerakan) adalah pengelolaan lingkungan organisasi dengan melibatkan lingkungan dan orang lain, tentunya dengan tata cara yang baik. ${ }^{37}$ Sehingga juga dapat dipahami bahwasanya actuating merupakan pelaksanaan dari planing dan organizing, sehingga kaitannya dengan pemasaran pendidikan dapat dipahami bahwasanya actuating merupakan mengubah planing dan organizing menjadi sebuah tindakan pemasaran atau kegiatan pemasaran untuk mencapai tujuan pemasaran.

Pelaksanaan atau penggerakan adalah proses mengalihkan rencana pemasaran menjadi kegiatan penugasan, dan diharapkan penugasan dapat dilaksanakan sesuai dengan harapan atau tujuan yang sudah disepakati. Untuk melaksanakan pemasaran perlu memiliki keterampilan yang berupa: ${ }^{38}$
(a) Keterampilan mengenali dan menentukan masalah

(b) Keterampilan menilai tingkat perusahaan, posisi masalah berada

(c) Keterampilan melaksanakan rencana

\footnotetext{
${ }^{36}$ Thamrin Abdullah dan Francis Tantri, Manajemen Pemasran., 73.

${ }^{37}$ Rahmat Hidayat H. Candra Wijaya, AyatAyat Alquran Tentang Manajemen Pendidikan Islam (Medan; LPPPI, 2017), 29.

${ }^{38}$ Manullang dan Esterlina, Manajemen
}

(d) Keterampilan

mengevaluasi hasil perencanaan

\section{4) Controling}

Robins menjelaskan: "control is the process of monitoring activities to ensure they are being accomplished as planned and of correcting any significant deviations". Dalam istilah lain, pemantauan adalah segala aktivitas untuk menjamin pencapaian tujuan yang telah direncanakan dan pemeriksaan terhadap adanya penyimpangan menjadi hakikat sebuah pengawasan. Pengawasan dapat dilaksanakan secara langsung (direct control) dan pengawasan tidak langsung (indirect control). ${ }^{39}$ Selain itu pengawasan tersebut juga dapat dilaksanakan dalam jangka pendek atau jangka panjang.

\section{Tujuan Pemasaran Jasa Pendidikan}

Pemasaran merupakan kegiatan yang berhubungan secara langsung dengan publik karena memang sasaran utama dari pemasaran adalah publik. Sehubungan dengan itu pemasaran memang ada untuk kepentingan eksistensi dari instansi, organisasi ataupun lembaga. Maka dari itu demi kelancaran pemasaran tentunya harus ada analisis, perencanaan, pelaksanaan, dan pengendalian pemasaran. Sedangkan beberapa tahap atau aktivitas tersbut berada di dalam ruang lingkup pemasaran untuk mencapai tujuan. Sedangkan tujuan sendiri

${ }^{39}$ Candra Wijaya dan Muhammad Rifa'i, Dasar-Dasar Manajemen., 45. 
berfungsi sebagai tolok ukur bagi eksistensi dari instansi, organisasi, ataupun lembaga. Beberapa tujuan dari pemasaran secara umum yaitu untuk memaksimalkan konsumsi, kepuasan konsumen, pilihan, dan kualitas hidup. ${ }^{40}$

Seperti yang telah dipaparkan di atas bahwasanya tujuan pemasaran secara umum memang berorientasi pada konsumen atau publik. Lain daripada itu, tujuan dari pemasaran adalah membuat produk perusahaan atau lembaga yang kompetitif dengan adanya nilai pembeda dengan kompetitor. Begitu pula dengan pemasaran jasa pendidikan, tujuan pemasaran adalah untuk memberikan arah dan tujuan pada kegiatan-kegiatan lembaga pendidikan, serta dalam orientasinya tujuan pemasaran lembaga pendidikan adalah memaksimalkan kepuasan konsumen. ${ }^{41}$ Sebagaimana yang telah dikemukakan oleh Kotler dan Fox yang pendapatnya dikutip oleh David dalam bukunya Pemasaran Jasa Pendidikan, dijelaskan bahwa tujuan pemasaran jasa pendidikan yaitu: ${ }^{42}$

a. Misi sekolah dapat tercapai dengan tingkat keberhasilan yang tinggi

${ }^{40}$ Samsul Anam, dkk., Manajemen Pemasaran (Surabaya: IAIN Sunan Ampel, 2013), 12.

${ }^{41}$ M. Munir, Manajemen Pemasaran Pendidikan Dalam Meningkatkan Kuantitas Peserta Didik, Intizam : Jurnal Manajemen Pendidikan Islam, Volume 1, $\underset{*}{\ddagger}$ Nomor 2, (April 2018), 82. 21

\footnotetext{
${ }^{42}$ David Wijaya, Pemasaran Jasa Pendidikan.,
}

b. Meningkatkan atas kepuasan pelanggan jasa pendidikan

c. Meningkatkan sumber daya pendidikan untuk menarik perhatian publik atau konsumen

d. Meningkatkan efisiensi dalam pemasaran jasa pendidikan.

3. Strategi Pemasaran Jasa Pendidikan

Setiap lembaga yang berdiri memiliki tujuan tertentu yang di mana tujuan tersebut menjadi kesepakatan bersama dengan adanya pemikiran yang sama. Begitu juga dengan lembaga pendidikan yang di mana tujuan pastinya untuk mencapai keberhasilan dalam pendidikan dan berorientasi penuh pada pendidikan dan serta hal lain yang berkaitan dengan pendidikan. Maka dari itu dalam mencapai tujuan bersama perlu adanya sebuah perencanaan, di mana perencanaan itu sebagai usaha mencapai tujuan.

Dalam lembaga pendidikan terdapat beberapa hal yang mampu mempengaruhi berlangsungnya proses pendidikan dan eksistensi lembaga tersebut di mata publik. Seperti halnya pemasaran jasa yang berorientasi dalam dunia pendidikan. Keberadaan pemasaran jasa pendidikan mampu memengaruhi eksistensi lembaga tersebut di dunia pendidikan, dan di pasaran atau publik. Maka dari itu pemasaran jasa pendidikan juga memiliki tugas untuk menentukan tujuan tujuan dari berdirinya lembaga pendidikan. 
Seperti yang telah diuraikan di atas bahwasanya tujuan pemasaran jasa perlu berjalan dengan jalan adanya perencanaan, perencanaan pemasaran jasa pendidikan dapat diorganisasikan melalui adanya strategi pemasaran jasa pendidikan yang meliputi segmentasi, penentuan pasar sasaran, dan penentuan posisi. Dengan adanya strategi tersebut diharapkan agar organisasi yang berada di pemasaran jasa pendidikan mampu bergerak secara aktif. Dan ketiga unsur tersebut meliputi:

a. Strategi penentuan pasar sasaran (target market strategy). Strategi ini bertujuan untuk mengidentifikasi segmen pasar dalam konteks pasar jasa pendidikan.

b. Strategi penentuan posisi pasar persaingan (comptitiv positioning strategy). Strategi ini bertujuan untuk mengidentifikasi atribut-atribut sekolah untuk menciptakan sekolah lebih menarik dan inovatif sehingga sekolah terlihat berbeda dari kompetitior yang memiliki segmen pasar yang sama.

c. Strategi bauran pemasaran (marketing mix strategy). Strategi ini merupakan kombinasi atas unsur-unsur yang disajikan oleh sekolah kepada stakeholder untuk mempromosikan jasa pendidikan. ${ }^{43}$ Adapun strategi bauran pemasaran terdiri dari 7 unsur

${ }^{43}$ David Wijaya, Pemasaran Jasa Pendidikan (Jakarta: Bumi Aksara, 2016), 90-91. Jurnal Intelektual: Jurnal Pendidikan dan Studi Keislaman Volume 10, Nomor 2, Agustus 2020
(7P) yang meliputi: product, price, promotion, place, people, process, customer service.

1) Product

Produk adalah apapun yang dihasilkan dan diciptakan oleh penyedia jasa, sedangkan produk sendiri berupa produk utama/inti, produk yang diharapkan, produk tambahan, dan produk potensial.

2) Price

Price / penentu harga yang berlaku di dunia pendidikan ditentukan berdasarkan pelayanan yang diberikan. Dengan penentu harga yang tepat akan mampu menciptakan citra produk yang baik dimata pelanggan.

3) Place

Place/lokasi yang dimaksud dalam hal ini adalah di mana lokasi untuk menyalurkan apa yang ditawarkan dan di mana lokasi usaha. Sedangkan aspek lokasi dan saluran pemillihannya tergantung dari kriteria pasar, dan sifat dari jasa sendiri.

4) Promosi

Promosi merupakan aktivitas mengomunikasikan perusahaan atau organisasi kepada publik, dalam promosi terdapat bauran promosi yaitu iklan, penjualan perorangan, 
promosi penjualan, hubungan

masyarakat, informasi dari mulut ke

mulut, surat pemberitahuan langsung.

5) People

People / orang yang dimaksud adalah pihak-pihak yang terlibat dalam pelaksanaan pendidikan, di mana pada tahap implementasi pihak-pihak tersebut berhubungan dengan kegiatan seleksi, pelatihan, motivasi, dan manajemen sumber daya manusia.

6) Proses

Makna dari proses dalam hal ini adalah gabungan dari beberapa aktifitas dari awal hingga akhir. Seperti penyusunan prosedur, jadwal pekerjaan, mekanisme, aktivitas, dan hal-hal rutin lainnya.

7) Layanan konsumen

Layanan yang diberikan oleh pelaksana pendidikan ditujukan kepada pengguna atau pelanggan pendidikan di mana hal ini bertujuan untuk mencapai kepuasan pelanggan. Layanan yang dimaksud dapat berupa memberikan kegunaan waktu dan tempat kepada pengguna atau pelanggan jasa pendidikan. ${ }^{44}$

\section{B. Usaha Mempertahankan dan \\ Meningkatkan Citra Positif \\ 1. Definisi Citra \\ Sekolah merupakan suatu organisasi} kelembagaan yang bergerak dalam bidang pendidikan yang memberikan pelayanan pada publik dalam hal pendidikan, dan tidak lain lagi jika sasaran sekolah adalah peserta didik dan masyarakat yang berada di lingkungannya. Sehingga sekolah juga tidak lepas dari peran masyarakat dan posisi masyarakat bagi sekolah.

Eksistensi sekolah dalam persepsi atau opini masyarakat/publik memiliki keterkaitan dengan persepsi masyarakat atau pandangan masyarakat terhadap sekolah. Sedangkan persepsi atau opini tersebut mampu mempengaruhi eksistensi sekolah di pasaran berdasarkan penawaran dan hasil yang diberikan sekolah pada masyarakat atau publik. Sehingga dengan begitu akan tercipta positive image atau citra positif. Citra positif sangat diperlukan oleh suatu sekolah, hal ini tidak lain adalah karena sekolah yang baik tentunya akan menjadi salah satu pertimbangan dalam pengambilan keputusan orang tua dalam menentukan pilihan terhadap sekolah tersebut. ${ }^{45}$

Kotler memberikan penjelasan tentang citra adalah seperangkat keyakinan, ide dan

\footnotetext{
${ }^{45}$ Siti Maamarah, Strategi Peningkatan Mutu
} Dan Citra (Image) Sekolah Dasar Negeri Di Ungaran, Semarang : Jurnal Kelola Volume 3, No 1 (JanuariJuni 2016), 118.
${ }^{44}$ Rambat Lupiyoai dan A. Hamdani, Manajemen Pemasaran Jasa edisi 2, 70-76. 
pengaruh yang didapat oleh seseorang dari suatu objek. ${ }^{46}$ Di mana sikap dan tindakan dari seseorang terhadap objek tersebut timbul adalah karena objek tersebut. Sedangkan pendapat lain mengatakan bahwa citra adalah sesuatu yang dijadikan pandangan masyarakat mengenai sebuah objek melalui apa yang mereka lihat maupun mereka dengar, sehingga masyarakat mampu memberikan penilaian pada objek tesebut. ${ }^{47}$

a. Jenis-jenis citra (image)

Citra merupakan bayangan yang tercemin dari sebuah organisasi atau suatu lembaga pendidikan yang di mana bayangan ini mampu menentukan seberapa banyak pelanggan atau masyarakat yang percaya pada lembaga pendidikan untuk menyekolahkan anaknya di suatu sekolah maka dari itu citra sendiri terbagi menjadi beberapa jenis yaitu mirror image, multiple image, dan current image.

\section{1) Multiple Image}

Multiple image merupakan citra yang dipandang seseorang melalaui apa yang mereka berikan pada publik. Maka dari itu apa yang diberikan akan menjadi image di mata publik, jika apa yang diberikan baik maka imagenya juga baik.

\footnotetext{
${ }^{46}$ Buchari Alma, Manajemen Pemasaran dan Pemasaran Jasa., 379.

${ }^{47}$ Onong Uchjana Effendi, Hubungan Masyarakat (Bandung: Remaja Rosdakarya, 1992),
} 166 . Jurnallntelektual: Jurnal Pendidikan dan Studi Keislaman Volume 10, Nomor 2, Agustus 2020
2) Mirror image

Kesan yang diperoleh karena produk yang diberikan baik pelanggan yang merasa puas maupun merasa kurang puas karena masih banyak kekurangan. Maka dari itu adanya perbaikan oleh karyawan perusahaan.

\section{3) Current Image}

Image umum yang beredar di masyarakat perlu diketahui oleh semua anggota organisasi sehingga bentuk kerjasama akan dapat terjalin untuk mengatasi permasalahan.

b. Faktor Terbentuknya Citra

Citra merupakan sebuah efek dari berlangsungnya suatu kegiatan yang melibatkan publik, munculnya citra tersebut dapat dilihat dari beberapa faktor yang mampu memengaruhi terbentuknya citra. Sedangkan berdasarkan penelitiannya Huddleston menyatakan bahwasanya beberapa faktor tersebut meliputi: academic reputation, campus appearance, cost, personal attention, location, distance from home, career placement,social activity, program study. ${ }^{48}$

2. Usaha Mempertahankan dan Meningkatkan Citra Positif Sekolah

Setiap program atau usaha terbentuk berdasarkan tujuan yang ingin dicapai. Dalam mencapai tujuan tersebut tidak lepas

${ }^{48}$ Buchari Alma, Manajemen Pemasaran dan Pemasaran Jasa., 382. 
dari usaha untuk mempertahankan apa yang sudah ada dan meningkatkan apa yang kurang atau yang perlu ditingkatkan. Begitu pula dengan citra sekolah, sekolah pastinya memiliki target atau kriteria tersendiri untuk mendapatkan nilai dari masyarakat atau publik sehingga perlu adanya usaha untuk mempertahankan dan meningakatkan citra posistif. Dalam hal ini biasanya dilakukan oleh warga sekolah terutama pihak humas berikut usaha humas dalam mempertahankan dan meningkatkan citra sekolah:

a) Membangun Komunikasi

1) Pengertian Komunikasi

Proses pembagian makna atau ide-ide di antara dua orang atau lebih dan mereka saling memahami antara maksud dari pesan yang disampaikan. ${ }^{49}$ Komunikasi adalah proses penyampaian dan penerimaan dari seseorang kepada orang lain secara tertulis, lisan maupun isyarat baik secara langsung (face to face) maupun tidak langsung (melalui media tertentu. $^{50}$

2) Proses Berlangsungnya Komunikasi.

Komunikasi yang terjalin antara marketing dengan stakeholder memiliki tahapan atau proses yang beruntun, adakalanya komunikasi tersebut terjadi secara langsung maupun tidak langsung, namun tidak menutup kemungkinan komunikasi terjalin dengan berbagai macam cara. Beberapa proses tersebut meliputi:

(a) Proses komunikasi secara primer.

Proses komunikasi secara primer biasanya terjadi penyampaian paduan antara pikiran dan perasaan seseorang secara langsung (face to face) kepada orang lain dengan menggunakan lambang atau simbol. Dalam keseharian lambang tersebut mengandung makna komunikasi verbal dan nonverbal. Lambang verbal terdiri dari katakata yang biasa digunakan untuk berkomunikasi.

Sedangkan nonverbal berupa media primer seperti halnya kial (gestur) gambar dan warna. ${ }^{51}$

(b) Komunikasi tatap muka sebagai komunikasi primer.

Penyampaian informasi oleh komunikator dan komunikan secara langsung (tatap muka) yang menggunakan bahasa sebagai media primer. Dalam berlangsungnya komunikasi ini dapat terjadi dua situasi yaitu 
komunikasi antar personal (antar pribadi) dan kelompok. ${ }^{52}$

(c) Proses komunikasi sekunder.

Proses komunikasi secara sekunder untuk menyampaikan informasi atau pesan dengan menggunakan media untuk menyampaikan informasinya. Media yang dimaksud dalam hal ini adalah sebuah benda yang bisa berwujud dan mampu menjadi sarana penyampaian informasi, seperti halnya radio, televisi dan lain sebagainya. ${ }^{53}$

\section{3) Komunikasi dan Opini Publik}

Berbicara mengenai opini publik tidak akan lepas dari fungsi komunikasi yang terjalin antara kedua belah pihak yang saling berkaitan. Dengan adanya komunikasi maka akan menimbulkan opini publik mengenai suatu objek. Seiring berjalannya waktu dan berlangsungnya komunikasi antara komunikan dan lawannya akan melahirkan sebuah opini baik dari publik maupun individu. Dan di mana opini tersebut menyangkut beberapa aspek yakni ekspresi, persoalan/isu yang dapat berarti pro kontra, dan kemasyarakatan. ${ }^{54}$

b. Meningkatkan Kualitas Jasa Pendidikan
Peningkatan kualitas jasa pendidikan sangatlah perlu untuk diwujudkan, hal ini dikarenan bahwa eksistensi suatu sekolah akan bergeser apabila kepuasan pelanggan jasa pendidikan (siswa, guru, orang tua siswa, dan pengguna jasa pendidikan) tidak terpenuhi. Selain itu kepuasan pelanggan dapat diukur dengan adanya kesenjangan antara harapan dan persepsi pelanggan terhadap kualitas pelayanan yang diberikan.

Adapun upaya peningkatan kepuasan pelanggan jasa melalui kualitas jasa pendidikan dapat diwujudkan menggunakan beberapa pendekatan. Sebagaimana pendapat Kotler yang dikutip oleh David mengenai pendekatan tersebut yaitu meliputi:

1) Meminimalisir kesenjangan antara pemimpin sekolah dengan pelanggan jasa pendidikan.

2) Pemimpin sekolah harus mampu membangun komitmen bersama seperti halnya membuat visi sekolah dengan tujuan memperbaiki proses pemasaran jasa pendidikan.

3) Pemimpin sekolah harus mampu memberikan kesempatan kepada pelanggan jasa pendidikan untuk menyampaikan keluhan.

4) Pemimpin sekolah harus mampu mengembangkan dan menerapkan pemasaran jasa dengan bertanggung jawab dan proaktif dalam menyikapi 
perkembangan

pemasaran

pendidikan. ${ }^{55}$

c. Meningkatkan Produk Jasa Pendidikan

Setiap sekolah mengharapkan masa depan yang baik, dan masa depan sekolah dapat ditentukan dari produk jasa pendidikan yang tercetak. Sedangkan dalam memenuhi kebutuhan pelanggan jasa perlu adanya usaha untuk meningkatkan produk jasa pendidikan. Adapun menurut Lockhart yang pendapatnya dikutip oleh David mnyatakan bahwasanya bauran produk jasa pendidikan meliputi siswa, kurikulum, aktifitas ekstrakurikuler, dan sekolah sebagai kegiatan masyarakat. Maka dari itu dengan adanya bauran produk jasa pendidikan dapat dijadikan sebagai langkah untuk meningkatkan produk jasa pendidikan dengan mengembangkan bauran pemasaran jasa pendidikan. ${ }^{56}$

1) Siswa

Siswa adalah objek pendidikan yang berupa orang/individu untuk mendapatkan pelayanan pendidikan sesuai dengan bakat, minat, dan kemampuannya agar tumbuh dan berkembang dengan baik serta mempunyai kepuasan dalam menerima pelajaran yang diberikan oleh gurunya. $^{57}$

2) Kurikulum
Kurikulum merupakan seperangkat alat sebagai rencana dan pengaturan mengenai tujuan, isi, dan bahan pelajaran serta digunakan sebagai pedoman penyelenggaraan kegiatan pembelajaran untuk mencapai tujuan pendidikan secara efektif dan efisien. ${ }^{58}$ Seperti halnya Kurikulum muatan lokal yang telah ditetapkan di sekolah dalam pengaplikasiannya perlu adanya inovasi sendiri dari pihak sekolah agar mampu mengembangkan kurikulum yang ada. Adapun pengembangan kurikulum di sini difokuskan dari sudut pandang kepentingan peserta didik dengan tujuan sebagai berikut: ${ }^{59}$

(a) Meningkatkan pemahaman peserta didik pada lingkungannya

(b)Mengakrabkan peserta didik dengan lingkungan.

(c) Menerapkan pengetahuan dan keterampilan yang dipelajari untuk memecahkan masalah di lingkungannya.

\section{3) Aktivitas Ekstrakurikuler}

Kegiatan ekstrakurikuler merupakan upaya untuk mengembangkan minat dan bakat peserta didik di luar kegiatan belajar mengajar (intrakurikuler) yang di mana kegiatan ini dapat dilakukan di

\footnotetext{
${ }^{55}$ David Wijaya, Pemasaran Jasa Pendidikan (Jakarta: Bumi Aksara, 2016), 183-184.

${ }^{56}$ Ibid., 105.

${ }^{57}$ Muhammad Kristiawan, dkk., Manajemen Pendidikan (Yogyakarta: Budi Utama, 2017), 69.
} 
lingkungan sekolah atau di luar

sekolah. Kegiatan ekstrakurikuler

diadakan dengan tujuan untuk

memperluas wawasan, kemampuan,

meningkatkan dan menetapkan nilai

pengetahuan yang telah dipelajari

dalam kegiatan belajar mengajar. ${ }^{60}$

Di antara kegiatan ekstrakurikuler yang banyak digunakan dan dikembangkan sekolah yaitu: kegiatan ekstra kurikuler keagamaan, paskibra, pramuka, kesenian (teater, marching band, tari, angklung, marawis, band, upacara adat), UKS, olahraga, bahasa, klub sains, ekstrakurikuler PAI dan lain sebagainya. ${ }^{61}$ Dengan adanya kegiatan ekstrakurikuler tersebut diharapkan nantinya akan meningkatkan kualitas sumber daya manusia melalui kegiatan ekstra yang ada, serta perlu dukungan dan peran serta pemasar jasa pendidikan untuk mengelola program ekstra dengan baik sehingga mampu memberikan peluang bagi siswa di sekolah.

\section{4) Sekolah Sebagai Pusat Kegiatan} Masyarakat.

Keberadaan sekolah di lingkungan masyarakat diharapkan mampu menjadi mitra yang dapat diandalkan serta mampu menjalin hubungan dan

${ }^{60}$ Bahrudin, Manajemen Peserta didik (Jakarta: Indeks, 2014), 47.

${ }^{61}$ Bahrudin, Manajemen Peserta didik ., 61. komunikasi yang baik dengan masyarakat melalui kegiatan masyarakat seperti ketersediaannya sekolah menjadi tempat pertemuan yang membahas masalah kewarganegaraan, tempat pemungutan suara, atau menyelenggarakan pendidikan bagi orang dewasa. ${ }^{62}$

\section{Kesimpulan}

Manajemen pemasaran jasa pendidikan dalam teori manajemen pemasaran sebagaimana teori yang ikutip oleh Agustina Shinta dalam bukunya Manajemen Pemasaran. Teori tersebut meliputi perencanaan pemasaran, pengorganisasian pemasaran, implementasi pemasaran, dan pengawasan pemasaran. Usaha meningkatkan dan mempertahankan citra positif adalah sebagaimana teori Hudleston mengenai faktor yang mampu membentuk citra, yaitu academic reputation (mutu akademik), dan mewujukannya dengan langkah meningkatkan kualitas jasa pendidikan, meningkatkan produk jasa pendidikan, dan ditambah usaha lainnya berupa membangun komunikasi, menerapkan kedisiplinan, memberikan pengarahan kepada alumni untuk menjaga nama baik almamater. Eksistensi pemasaran jasa pendidikan dalam meningkatkan citra adalah bahwa pemasaran jasa pendidikan yang

\footnotetext{
${ }^{62}$ David Wijaya, Pemasaran Jasa Pendidikan .,
} 
dilaksanakan dengan jalan promosi program pembelajaran unggulan, kegiatan positif di luar sekolah, dan dengan perencanaan program yang tersistem dengan baik telah berhasil meningkatkan dan mempertahankan citra sekolah.

\section{Daftar Pustaka}

A. Muri Yusuf, Metode Penelitian Kuantitatif, Kualitatif dan Gabungan (Jakarta: Kencana, 2017)

Abdul Rahmat, Manajemen Humas Sekolah (Yogyakarta: Media Akademi, 2016)

Agustina Shinta, Manajemen Pemasaran (Malang: Universitas Brawijaya Press, 2011)

Ali Nurdin, dkk., Pengantar Ilmu Komunikasi (Surabaya: Mitra Media Nusantara, 2013)

Bahrudin, Manajemen Peserta didik (Jakarta: Indeks, 2014)

Buchari Alma, Manajemen Pemasaran dan Pemasaran Jasa (Bandung: Alfabeta, 2018)

Burhan Bungin, Metode Penelitian Kualitatif (Jakarta: PT. Raja Grafindo Persada, 2001)

Candra Wijaya dan Muhammad Rifa'i, Dasar-Dasar Manajemen (Medan: Perdana Publishing, 2016)

David Wijaya, Pemasaran Jasa Pendidikan (Jakarta: Bumi Aksara, 2016)

Frazier Moore, Humas membangun citra dengan komunikasi, ( Bandung: Remaja Rosdakarya, 2005)

Ibnu Subiyanto, Metodologi Penelitian (TT:
Jonathan Sarwono, Metode Penelitian Kuantitatif dan Kualitatif (Yogyakarta: Graha Ilmu, 2006)

M. Munir, Manajemen Pemasaran Pendidikan Dalam Meningkatkan Kuantitas Peserta Didik, Intizam : Jurnal Manajemen Pendidikan Islam, Volume 1, Nomor 2, (April 2018)

Manullang dan Esterlina, Manajemen Pemasaran (Yogyakarta: Indomedia Pustaka, 2016)

Muhammad Kristiawan, Dkk, Manajemen Pendidikan, (Yogyakarta: Deepublish, 2017)

Onong Uchjana Effendi, Hubungan Masyarakat (Bandung: Remaja Rosdakarya, 1992)

Rahmat Hidayat H. Candra Wijaya, AyatAyat Alquran Tentang Manajemen Pendidikan Islam (Medan; LPPPI, 2017)

Rambat Lupiyoai dan A. Hamdani, Manajemen Pemasaran Jasa edisi 2, (Jakarta: Salemba Empat, 2006)

Samsul Anam, dkk., Manajemen Pemasaran (Surabaya: IAIN Sunan Ampel, 2013)

Siti Farikhah, Manajemen Lembaga Pendidikan (Yogyakarta: Aswaja Perssindo, 2015)

Siti Maamarah, Strategi Peningkatan Mutu Dan Citra (Image) Sekolah Dasar Negeri Di Ungaran, Semarang : Jurnal Kelola Volume 3, No 1 (Januari-Juni 2016)

Suharsimi Arikunto, Prosedur Penelitian (Jakarta: Pt Rineka Cipta, 2010)

Suharsimi Arikunto, Prosedur Penelitian Suatu Pendekatan Praktik (Jakarta: Rineka Cipta, 2014) 
Sumaryanto, "Strategi Sukses Bagi Usaha Pemasaran Jasa Pendidikan Berbasis Manajemen Proses", dalam Jurnal Ekonomi Dan Kewirausahaan, vol. 11, no. 1, (April 2011)

Suvidiana Elytasari, "Strategi Pemasaran Jasa Pendidikan Untuk Meningkatkan Kepercayaan (Trust) Stakeholders di TK Amal Insani Depok Yogyakarta" dalam Jurnal Warna vol. 1, no. 1, (Juni 2017)

Thamrin Abdullah dan Francis Tantri, Manajemen Pemasaran (Depok: Raja Grafindo Persada, 2012)

Widodo Winarso, Dasar Pengembangan Kurikulum Sekolah (Cirebon, 2015) 